\title{
Growth Performance and Nutrient Uptake of Oil Palm Seedling in Prenursery Stage as Influenced by Oil Palm Waste Compost in Growing Media
}

\author{
A. B. Rosenani, R. Rovica, P. M. Cheah, and C. T. Lim \\ Department of Land Management, Faculty of Agriculture, Universiti Putra Malaysia (UPM), 43400 Serdang, Selangor, Malaysia \\ Correspondence should be addressed to A. B. Rosenani; rosenani.abubakar@gmail.com
}

Received 5 November 2015; Accepted 14 January 2016

Academic Editor: Iskender Tiryaki

Copyright (c) 2016 A. B. Rosenani et al. This is an open access article distributed under the Creative Commons Attribution License, which permits unrestricted use, distribution, and reproduction in any medium, provided the original work is properly cited.

\begin{abstract}
The use of composted oil palm wastes in the oil palm nursery as an organic component of growing medium for oil palm seedlings seems promising in sustainable oil palm seedling production. This study was conducted to investigate the effects of six oil palm waste compost rates $(0,20,40,60,80$, and $100 \%)$ on the growth performance of oil palm seedling and nutrient uptake in the prenursery stage (0-3 months). The addition of oil palm compost reduced the soil bulk density $\left(1.32\right.$ to $\left.0.53 \mathrm{~g} \mathrm{~cm}^{-3}\right)$ and increased soil $\mathrm{pH}$ (4.7 to 5.1) of growth media. Oil palm waste compost treatment produced positive growth performance up to $70 \%$. A regression analysis indicated in $72 \%$ of compost and topsoil mixture as a polybag growth medium was optimum in producing best growth performance of oil palm seedling in the prenursery stage. Foliar analysis implied highest nutrients uptake ( N, P, K, Mg, Ca, Fe, Zn, and $\mathrm{Cu}$ ) for seedlings grown in 60 to $100 \%$ compost media.
\end{abstract}

\section{Introduction}

Oil palm (Elaeis guineensis) was first introduced to Malaysia in 1870 as an ornamental plant. However, the cultivation of oil palm dates back to 1917 and only in the last 50 years was the rubber industry replaced by oil palm cultivation as the main commercial crop in the agriculture sector [1]. The total planted area had then rapidly increased from 1.5 million hectares in 1985 to 5.39 million hectares in 2014 [2]. Currently, Malaysia is the second largest palm oil producer $(39 \%)$ and exporter (44\%) in the world [2]. This industry is a significant contributor toward economic growth but it also contributes toward environmental pollution due to the large amount of by-product produced during the oil extraction process. It is estimated that 53 million tonnes of oil palm waste residue was generated every year with a 5\% increment annually [3]. These oil palm wastes are rich in nutrients and present potential agronomic values. For instance, oil palm waste is suitable as raw material for composting to reduce the volume and recycle the nutrients. Currently, the oil palm empty fruit bunch (EFB) is applied in raw or unprocessed form to newly transplanted palms as mulch and nutrient source.
Topsoil has been conventionally used as the growing medium for oil palm seedling during nursery stage. However, it is not practical for long term due to the increasing nutrient demand of oil palm seedling and depletion of fertile soils. The production of high quality seedlings is dependent on good growing media. The physicochemical and biological properties of a growing medium will affect plant growth and directly influence roots growth. Furthermore, the planting medium must be porous and well drained to permit free roots penetration, secure anchorage, and have sufficient nutrients to support crop growth [4].

Amendment materials such as dry effluent and coir dust [5], organic-based substrate [6], and oil palm waste compost $[7,8]$ in soil growing media for oil palm seedling have been reported prior to this study. The positive effects of compost in raising seedlings include changes in the soil physical properties, exchange and buffering capacities, and being a direct source of nutrients for plants. Study by Aisueni and Omoti [9] in Nigeria found that application of composted EFB with POME at rate of $150 \mathrm{~g}$ per polybag increased seedling dry matter weight up to $71 \%$ at the main nursery stage. Previous study by Siregar et al. [10] conducted in Riau, 
TABLE 1: Selected physical and chemical characteristics of growing media.

\begin{tabular}{lcccccccccccc}
\hline Treatments & $\begin{array}{c}\text { Bulk density } \\
\left(\mathrm{g} \mathrm{cm}^{-3}\right)\end{array}$ & $\begin{array}{c}\mathrm{pH} \\
\left(\mathrm{H}_{2} \mathrm{O}\right)\end{array}$ & $\begin{array}{c}\mathrm{C}: \mathrm{N} \\
\text { Ratio }\end{array}$ & $\mathrm{C}$ & $\mathrm{N}$ & $\mathrm{P}$ & $\mathrm{K}$ & $\mathrm{Ca}$ & $\mathrm{Mg}$ & $\mathrm{Mn}$ & $\begin{array}{c}\mathrm{Zn} \\
(\%)\end{array}$ & \\
\hline $\mathrm{C} 0$ & $1.32^{\mathrm{a}}$ & $4.68^{\mathrm{e}}$ & $23.89^{\mathrm{d}}$ & $2.75^{\mathrm{f}}$ & $0.12^{\mathrm{f}}$ & $0.24^{\mathrm{e}}$ & $0.56^{\mathrm{a}}$ & $0.11^{\mathrm{d}}$ & $0.09^{\mathrm{d}}$ & $18.25^{\mathrm{c}}$ & $22.25^{\mathrm{d}}$ & $11.75^{\mathrm{cb}}$ \\
$\mathrm{C} 20$ & $1.24^{\mathrm{b}}$ & $4.85^{\mathrm{d}}$ & $26.05^{\mathrm{cd}}$ & $5.72^{\mathrm{e}}$ & $0.22^{\mathrm{e}}$ & $0.31^{\mathrm{d}}$ & $0.56^{\mathrm{a}}$ & $0.15^{\mathrm{cd}}$ & $0.13^{\mathrm{d}}$ & $22.00^{\mathrm{ab}}$ & $29.25^{\mathrm{cb}}$ & $13.00^{\mathrm{b}}$ \\
$\mathrm{C} 40$ & $1.11^{\mathrm{b}}$ & $5.08^{\mathrm{c}}$ & $28.23^{\mathrm{bc}}$ & $10.65^{\mathrm{d}}$ & $0.38^{\mathrm{d}}$ & $0.35^{\mathrm{d}}$ & $0.57^{\mathrm{a}}$ & $0.18^{\mathrm{c}}$ & $0.15^{\mathrm{d}}$ & $24.25^{\mathrm{a}}$ & $25.50^{\mathrm{cd}}$ & $12.00^{\mathrm{cb}}$ \\
$\mathrm{C} 60$ & $0.95^{\mathrm{bc}}$ & $5.13^{\mathrm{a}}$ & $31.33^{\mathrm{b}}$ & $18.47^{\mathrm{c}}$ & $0.59^{\mathrm{c}}$ & $0.49^{\mathrm{c}}$ & $0.53^{\mathrm{a}}$ & $0.22^{\mathrm{b}}$ & $0.22^{\mathrm{c}}$ & $19.50^{\mathrm{bc}}$ & $23.75^{\mathrm{d}}$ & $9.75^{\mathrm{c}}$ \\
$\mathrm{C} 80$ & $0.75^{\mathrm{cd}}$ & $5.15^{\mathrm{a}}$ & $29.78^{\mathrm{b}}$ & $28.32^{\mathrm{b}}$ & $0.95^{\mathrm{b}}$ & $0.83^{\mathrm{b}}$ & $0.56^{\mathrm{a}}$ & $0.26^{\mathrm{a}}$ & $0.28^{\mathrm{b}}$ & $21.75^{\mathrm{ab}}$ & $32.25^{\mathrm{b}}$ & $13.75^{\mathrm{b}}$ \\
$\mathrm{C} 100$ & $0.56^{\mathrm{d}}$ & $5.10^{\mathrm{b}}$ & $61.51^{\mathrm{a}}$ & $73.19^{\mathrm{a}}$ & $1.19^{\mathrm{a}}$ & $1.24^{\mathrm{a}}$ & $0.55^{\mathrm{a}}$ & $0.26^{\mathrm{a}}$ & $0.35^{\mathrm{a}}$ & $21.50^{\mathrm{ab}}$ & $46.25^{\mathrm{a}}$ & $23.00^{\mathrm{a}}$ \\
\hline
\end{tabular}

Note: means with the same letter within row are not significantly different at $p<0.05$ according to LSD test. C0, C20, C40, C60, C80, and C100 represent 0 , $20,40,60,80$, and $100 \%$ of compost, respectively.

Indonesia, reported that mixing $7.5 \mathrm{~kg}$ EFB compost together with topsoil could replace the standard mineral fertilization in main nursery stage as the 12-month-old seedling grows as good as seedlings under normal fertilization practices. Ovie et al. [11] reported that, under water stress condition, the use of $300 \mathrm{~g}$ of EFB and poultry manure compost $(4: 1$ ratio) in oil palm seedlings planting media resulted in significant improvement of plant vegetative growth and soil chemical properties when compared to seedling practices under conventional main nursery establishment.

Earlier reports of oil palm waste application on oil palm seedling were mainly on raw EFB during the main nursery stage. In this study, a different type of oil palm waste, the oil palm mesocarp, was utilized and focused on the prenursery stage (rather than the main nursery stage) to produce high quality seedlings. Thus, the aims of this study were to investigate the effects of oil palm waste compost which consisted of pressed oil palm fruit mesocarp and palm oil mill effluent (POME) as a component of polybag medium on growth performance of oil palm seedlings and nutrients uptake during the prenursery stage (0-3 months) in the double stage nursery system.

\section{Materials and Methods}

This study was conducted under shelter in Universiti Putra Malaysia $\left(2^{\circ} 59^{\prime} 59 \mathrm{~N}, 101^{\circ} 42^{\prime} 25 \mathrm{E}\right)$ with air temperature of $24-$ $33^{\circ} \mathrm{C}$. Oil palm waste of pressed oil palm fruit mesocarp and POME were obtained from Golden Hope Plantation Berhad and composted in Universiti Putra Malaysia. Oil palm seeds, GH500, a cross-breed product between Elite Deli Dura and second generation of Pesifera, BM119, were used in this study. Polybag media were prepared by mixing compost with the Serdang series topsoil (Ultisol, Tipik Lutualemkuts) at the ratio of $0(\mathrm{C} 0), 20(\mathrm{C} 20), 40$ (C40), 60 (C60), 80 (C80), and $100 \%(\mathrm{C} 100)$. The characteristics of the topsoil and oil palm waste compost were similar to C0 (topsoil only without compost) and $\mathrm{C} 100$ (solely compost), respectively. The experiment was carried out in a randomized complete block design (RCBD) with six replications.

Planting distance between each of the poly bags in the block was $30 \mathrm{~cm}$ and was $50 \mathrm{~cm}$ between each of the blocks. One germinated oil palm seed (GH500) was sown in each polybag of $15 \mathrm{~cm} \times 23 \mathrm{~cm}$ with equal volume of media.
The seedlings were watered twice a day and weeding was done manually. A compound fertilizer, N-P-K-Mg (14:7:9:2.5), was applied weekly ( $1.0 \mathrm{~g}$ per polybag) from week 7 to week 12 after sowing.

Plant height was recorded during the 12 weeks of prenursery period at weeks $1,2,4,6,8,10$, and 12 . All seedlings were left to grow until the 12th week (Figure 4). At the 12th week, chlorophyll content was recorded using a chlorophyll meter (SPAD 502 Plus Chlorophyll Meters). The seedlings were harvested $2 \mathrm{~cm}$ above ground for the shoot weight, while the roots were carefully removed from the polybag to record root weight. Fresh weight was recorded and the plant samples were oven-dried at $55^{\circ} \mathrm{C}$ until constant weight was achieved. Then, seedling (excluded root) was ground using a tissue grinder (IKA Labortechnik, MF10 Basic) for macroand micronutrients analysis. Total $\mathrm{N}$ and selected nutrients were determined using Kjeldahl method [12] and dry ashing method [13], respectively. Concentrations of $\mathrm{N}, \mathrm{P}$, and $\mathrm{K}$ were measured by Auto-Analyzer (LACHAT Instrument, QuikChem FIA+ 8000 series), while Ca, Mg, Fe, Cu, Zn, Mn, and Fe were measured via Atomic Adsorption Spectrometer (AAS; PerkinElmer Analyst 400), respectively.

Each medium treatment was analyzed for bulk density, $\mathrm{pH}(1: 4$, soil : water), and macro- and micronutrient contents as shown in Table 1. Bulk density was measured according to the core method [14]. Total N was determined using Kjeldahl method [12], total organic carbon (TOC) was determined with Walkey and Black [15], available $\mathrm{P}$ was determined according to Bray and Kurtz [16], and selected nutrients (K, $\mathrm{Mg}, \mathrm{Ca}, \mathrm{Fe}, \mathrm{Cu}, \mathrm{Zn}$, and $\mathrm{Mn}$ ) were determined with dry ashing method [13]. $\mathrm{N}$ and $\mathrm{P}$ concentrations were measured by Auto-Analyzer (LACHAT Instrument, QuikChem FIA+ 8000 series). Other elements ( $\mathrm{K}, \mathrm{Mg}, \mathrm{Ca}, \mathrm{Fe}, \mathrm{Cu}, \mathrm{Zn}$, and $\mathrm{Mn}$ ) were determined by Atomic Adsorption Spectrometer (AAS; PerkinElmer Analyst 400).

Analysis of variance (ANOVA) was performed for all parameters with the statistical analysis system, SAS version 9.2 (SAS Institute, Inc., Cary, NC, USA). Differences between treatments were analysed using LSD at $p<0.05$. Regression analyses (with ANOVA) were performed with Sigma Plot version 11.0 (Systat Software, San Jose, CA) to determine the relationships between oil palm waste compost and the chemical characteristics of the media and the growth parameters and nutrient contents of oil palm seedling. Initial characteristics of the treated growing media characteristic were analysed 


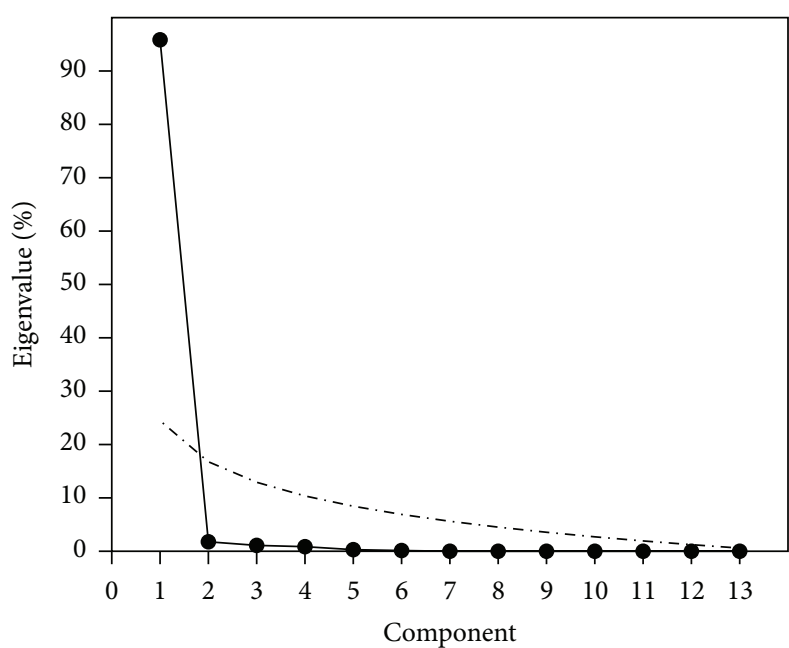

(a)

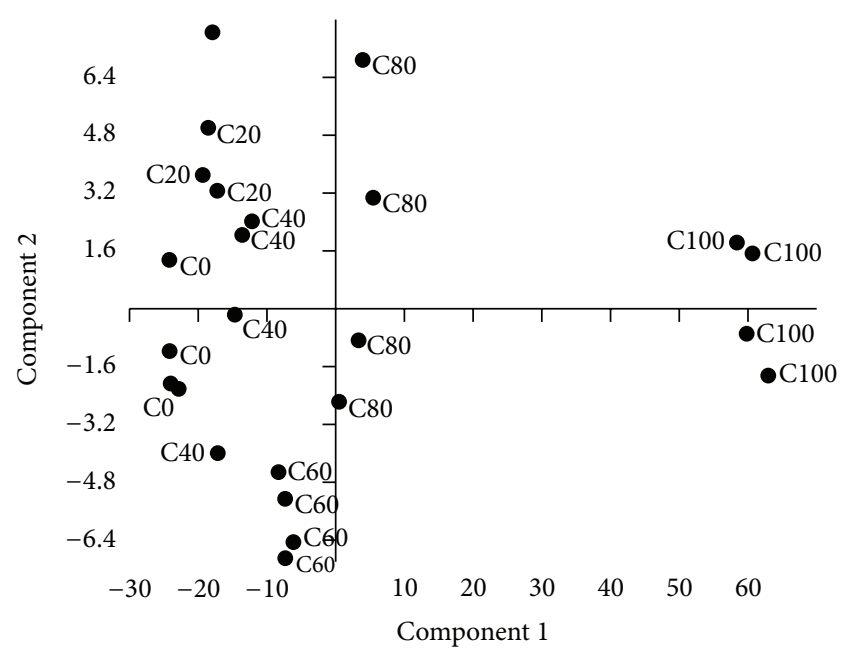

(b)

FIGURE 1: (a) Scree plot of eigenvalue. (b) Principal components analysis (PCA) of initial physicochemical properties of growing media (-.broken stick. C0, C20, C40, C60, C60, C80, and C100 represent 0, 20, 40, 60, 80, and 100\% of compost, resp.).

with PCA (PAST version 3.07, PAST: Paleontological Statistics Software, Paleontological Association) to determine the most prominent factor induced by compost addition on the overall alteration of the growing media.

\section{Results}

3.1. Physicochemical Characteristics of Growing Media. The $\mathrm{pH}$ value of growing media significantly increased from 4.68 in $\mathrm{C} 0$ and peaked at 5.15 in $\mathrm{C} 80$. Thus, the $\mathrm{pH}$ value for mixture of compost and topsoil of C60 and C80 was significantly higher than pure compost (C100). Mixing the compost with topsoil reduced the bulk density by up to $43 \%$ from the original topsoil $(\mathrm{C} 0)$ and there was no significant difference between C80 and C100 (Table 1). In general, the optimum bulk density of potting growing media is about $0.40 \mathrm{~g} \mathrm{~cm}^{-3}$ [17]. The $\mathrm{C}$ content of growing media significantly increased with $100 \%$ compost $(73.19 \%)$ as compared to control treatment, C0, with only $2.75 \%$ C (Table 1). Furthermore, $\mathrm{N}$ content of the treatments increased significantly with increasing amount of compost incorporated. The $\mathrm{C} / \mathrm{N}$ ratio of $\mathrm{C} 100$ (61.51) was significantly higher than the other treatments (23-31) due to higher presence of $\mathrm{C}$ associated with increasing amount of compost. However, $\mathrm{C} 100$ was not suitable as potting media due to the high $\mathrm{C} / \mathrm{N}$ ratio as the ideal range was recommended to be between 20 and 40 [18]. There was no significant difference between C40 and C80 (Table 1). Correspondingly, $\mathrm{P}, \mathrm{Ca}$, and $\mathrm{Mg}$ contents of soilcompost mixtures increased significantly when compared to C0 (Table 1). However, $\mathrm{K}$ content was not affected by the addition of compost and this could be attributed to leaching, commonly reported for $\mathrm{K}$ loss [19, 20]. In general, micronutrients $(\mathrm{Mn}, \mathrm{Zn}$, and $\mathrm{Cu})$ concentrations were increased with the addition of compost to the soil (Table 1), which might be contributed by the compost itself (C100).
TABLE 2: Factor pattern, eigenvalues, and percentages of the variance explained by each factor, obtained from the first PCA performed on the physicochemical properties of growing media.

\begin{tabular}{lccc}
\hline & PC 1 & PC 2 & PC 3 \\
\hline Soil pH & 0.003 & -0.010 & -0.028 \\
Bulk density $\left(\mathrm{g} \mathrm{cm}^{-3}\right)$ & -0.008 & 0.008 & 0.033 \\
$\mathrm{C}: \mathrm{N}$ ratio & 0.444 & -0.213 & 0.829 \\
$\mathrm{C} \%$ & 0.840 & -0.230 & -0.474 \\
$\mathrm{~N} \%$ & 0.012 & -0.006 & -0.055 \\
$\mathrm{P} \%$ & 0.012 & 0.001 & -0.031 \\
$\mathrm{~K} \%$ & 0.000 & 0.002 & -0.002 \\
$\mathrm{Ca} \%$ & 0.001 & -0.002 & -0.010 \\
$\mathrm{Mg} \%$ & 0.003 & -0.001 & -0.011 \\
$\mathrm{Cu}(\mathrm{mg} / \mathrm{kg})$ & 0.140 & 0.376 & 0.171 \\
$\mathrm{Zn}(\mathrm{mg} / \mathrm{kg})$ & 0.270 & 0.834 & -0.025 \\
$\mathrm{Mn}(\mathrm{mg} / \mathrm{kg})$ & 0.010 & 0.221 & -0.026 \\
$\mathrm{Na}(\mathrm{mg} / \mathrm{kg})$ & 0.061 & 0.127 & 0.228 \\
Eigenvalue & 841.176 & 15.539 & 9.631 \\
$\%$ variance & 95.845 & 1.7705 & 1.0974 \\
\hline
\end{tabular}

PCA of the chemical properties of growth media was generated (Table 2). The physicochemical properties of growing media (soil pH, bulk density, and total C, N, P, K, Ca, Mg Zn, $\mathrm{Cu}, \mathrm{Mn}$, and $\mathrm{Na}$ ) were regarded as independent factor and PCA was conducted using variance-covariance matrix. The eigenvalue scree plot (Figure 1(a)) showed one factor analysis. Besides, PC 1 explained $95.85 \%$ of the total variance and was primary associated with $\mathrm{C}$ content (Table 2). The PCA score plot revealed that the growing media properties were categorized according to the volume of compost content as C100 was clearly separated from other treatments (Figure 1(b)). This was attributed to the high C content in C100 (73.17\%). 
TABLE 3: Effect of compost addition in growing media on nutrients uptake by oil palm seedlings.

\begin{tabular}{|c|c|c|c|c|c|c|c|c|c|}
\hline Treatments & $\mathrm{N}$ & $\mathrm{P}$ & $\begin{array}{c}\mathrm{K} \\
\text { mg plant }^{-1}\end{array}$ & $\mathrm{Ca}$ & $\mathrm{Mg}$ & \multicolumn{4}{|c|}{$\mu$ g plant $^{-1}$} \\
\hline $\mathrm{CO}$ & $12.60^{\mathrm{b}}$ & $8.39^{c}$ & $11.43^{\mathrm{d}}$ & $3.00^{\mathrm{b}}$ & $2.83^{\mathrm{b}}$ & $25.86^{\mathrm{b}}$ & $53.35^{\mathrm{b}}$ & $110.12^{\mathrm{a}}$ & $509.79^{b}$ \\
\hline $\mathrm{C} 20$ & $16.80^{\mathrm{b}}$ & $11.78^{b c}$ & $13.52^{\mathrm{cd}}$ & $3.09^{\mathrm{b}}$ & $4.45^{\mathrm{b}}$ & $28.42^{\mathrm{b}}$ & $49.67^{\mathrm{b}}$ & $110.63^{\mathrm{a}}$ & $373.19^{c}$ \\
\hline $\mathrm{C} 40$ & $19.30^{\mathrm{b}}$ & $14.53^{\mathrm{b}}$ & $15.66^{\mathrm{c}}$ & $3.42^{\mathrm{b}}$ & $4.28^{\mathrm{b}}$ & $28.10^{\mathrm{b}}$ & $57.63^{\mathrm{b}}$ & $121.83^{\mathrm{a}}$ & $436.94^{b c}$ \\
\hline C60 & $29.66^{\mathrm{a}}$ & $25.72^{\mathrm{a}}$ & $19.70^{\mathrm{b}}$ & $5.12^{\mathrm{a}}$ & $6.44^{\mathrm{a}}$ & $44.48^{\mathrm{a}}$ & $86.73^{\mathrm{a}}$ & $142.56^{\mathrm{a}}$ & $739.40^{\mathrm{a}}$ \\
\hline $\mathrm{C} 80$ & $33.68^{\mathrm{a}}$ & $24.21^{\mathrm{a}}$ & $24.01^{\mathrm{a}}$ & $5.71^{\mathrm{a}}$ & $6.53^{\mathrm{a}}$ & $52.50^{\mathrm{a}}$ & $92.00^{\mathrm{a}}$ & $135.35^{\mathrm{a}}$ & $675.38^{\mathrm{a}}$ \\
\hline $\mathrm{C} 100$ & $32.48^{\mathrm{a}}$ & $27.76^{\mathrm{a}}$ & $21.38^{\mathrm{ab}}$ & $4.89^{\mathrm{a}}$ & $6.44^{\mathrm{a}}$ & $43.91^{\mathrm{a}}$ & $85.15^{\mathrm{a}}$ & $105.74^{\mathrm{a}}$ & $752.78^{\mathrm{a}}$ \\
\hline
\end{tabular}

Note: means with the same letter within row are not significantly different at $p<0.05$ according to LSD test. C0, C20, C40, C60, C80, and C100 represent 0 , $20,40,60,80$, and $100 \%$ of compost, respectively.

Therefore, C content largely affected the physicochemical properties in growth media.

3.2. Macro- and Micronutrients Uptake by Oil Palm Seedlings. The nutrients uptake of oil palm seedlings is shown in Table 3. In general, there was no significant difference between topsoil (C0) and topsoil-compost mixtures up to 40\% (C20-40). However, the macronutrients uptake increased significantly at $\mathrm{C} 60$ and there was no further significant rise subsequently. Likewise, $\mathrm{Cu}, \mathrm{Zn}$, and $\mathrm{Fe}$ uptakes imitated the pattern of macronutrients uptake; no significant difference was detected at low compost rate $(\mathrm{C} 0-40)$ but it increased significantly at C60 and remained stagnant successively (C60-100).

3.3. Oil Palm Seedlings Growth. Based on the regression studies, the shoot dry weight, root dry weight, plant height, and SPAD reading of oil palm seedlings were related to the amount of compost added (Figure 2). Hence, the shoot dry weight was best fitted into a positive quadratic relationship $(p \leq 0.001)$ with compost $\left(\mathrm{R}^{2}=0.725\right)$. It peaked at $\mathrm{C} 80$ and declined afterwards. Meanwhile, the root dry weight was also best fitted into a positive quadratic relationship ( $p \leq 0.01)$ with compost $\left(\mathrm{R}^{2}=0.496\right)$ and the highest root dry weight was detected at $\mathrm{C} 100$. The plant height was directly proportional or positive linearly related $(p \leq 0.001)$ with compost $\left(\mathrm{R}^{2}=0.534\right)$. Meanwhile, the SPAD was best fitted into a positive quadratic relationship $(p \leq 0.001)$ with compost $\left(\mathrm{R}^{2}=0.717\right)$ and peaked at C80. Addition of compost up to $72 \%$ in growing media resulted in progressive seedlings growth, but shoot dry weight started to decrease when more than $72 \%$ of compost was added (Figure 2(a)). SPAD value also showed a strong correlation $(p=0.01)$ to the seedlings nitrogen uptake (Figure 3 ).

\section{Discussion}

4.1. Effects of Oil Palm Waste Compost on the Characteristics of Growth Media. Addition of oil palm waste compost decreased the bulk density of topsoil-compost growing medium. This could be attributed to the dilution effect [21] as bulk density of compost was significantly lower than topsoil and higher amount of compost. Thus, compost addition improved soil aeration and pore space. Bronick and Lal [22] had shown that organic amendments such as compost have a dilution effect in lowering bulk density. Organic applications (e.g., compost) increased soil C content and also improved soil aggregation and macroporosity and lowered the penetration resistance, contributing to better crop growth $[23,24]$. This further highlighted the importance of compost in growing medium to alleviate soil $\mathrm{C}$ content and improved soil physical properties.

Adding compost also improved the chemical properties of the growing medium as shown by various studies, which reported the ability of compost to reduce soil acidity [2527]. This could be attributed to the presence of complex humic acid in compost [28] which provided binding sites for exchangeable bases and decreased the availability of polycations like $\mathrm{Fe}^{2+}$ and $\mathrm{Al}^{3+}$ [29]. Thus, addition of compost-C rich in negative functionalities could affect the $\mathrm{pH}$ value of the growth media. Besides, the high content of alkaline elements (excess cations), $\mathrm{Ca}$ and $\mathrm{Mg}$, was concomitant with increasing compost which could react with the free $\mathrm{H}^{+}$. This explained the liming effect of compost and decarboxylation of organic anions during decomposition, improving the $\mathrm{pH}$ of growing media [30].

Furthermore, compost could also supply the seedlings with additional $\mathrm{N}, \mathrm{P}, \mathrm{Ca}, \mathrm{Mg}$, and $\mathrm{Zn}$, functioning as a source of nutrients beside applied fertilizers. Another plausible mechanism was compost retaining the nutrients in the growing media by surface adsorption and increased nutrient recovery [31]. Vegetal compost was shown to be effective in removing $\mathrm{Zn}$ via sorption process [32]. Potassium was mostly leached away as it existed in ionic form $\left(\mathrm{K}^{+}\right)$and can be easily dissolved.

4.2. Effects of Oil Palm Waste Compost on Seedling Growth and Nutrients Uptake. The oil palm seedling growth and physiology improved with the application of compost. This was majorly attributed to the alteration of physicochemical properties of the growing medium. Multiple regression study showed that root and shoot growth and macronutrients uptake were highly significantly related to the $\mathrm{pH}$ of the growing media (Table 4). Previous studies also reported plants, specifically lettuce and ornamental plant, showing similar response when the growing medium improved from acidic to slightly acidic $[33,34]$. This highlighted the effect of $\mathrm{pH}$ on the nutrient availability as macronutrients like $\mathrm{P}$ were heavily affected by the $\mathrm{pH}$ value and subsequently 


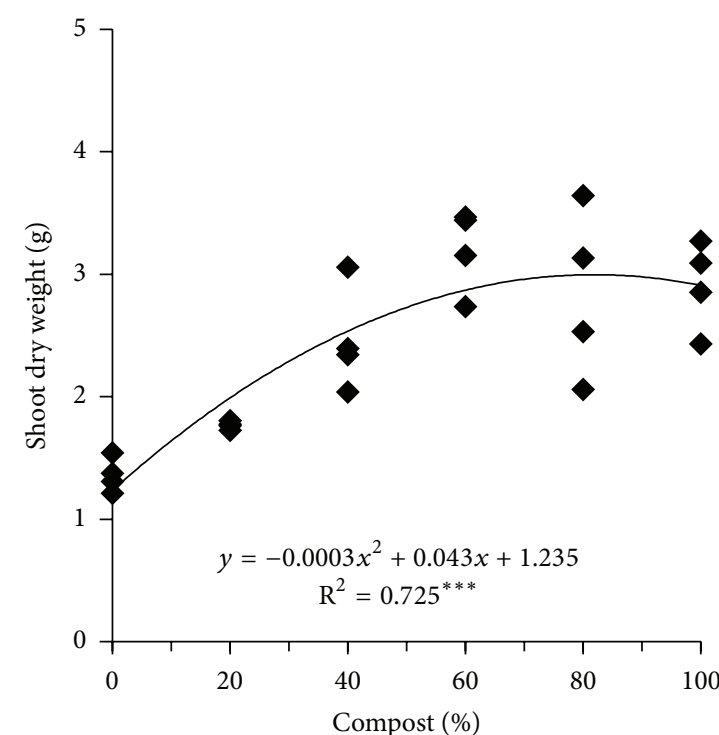

(a)

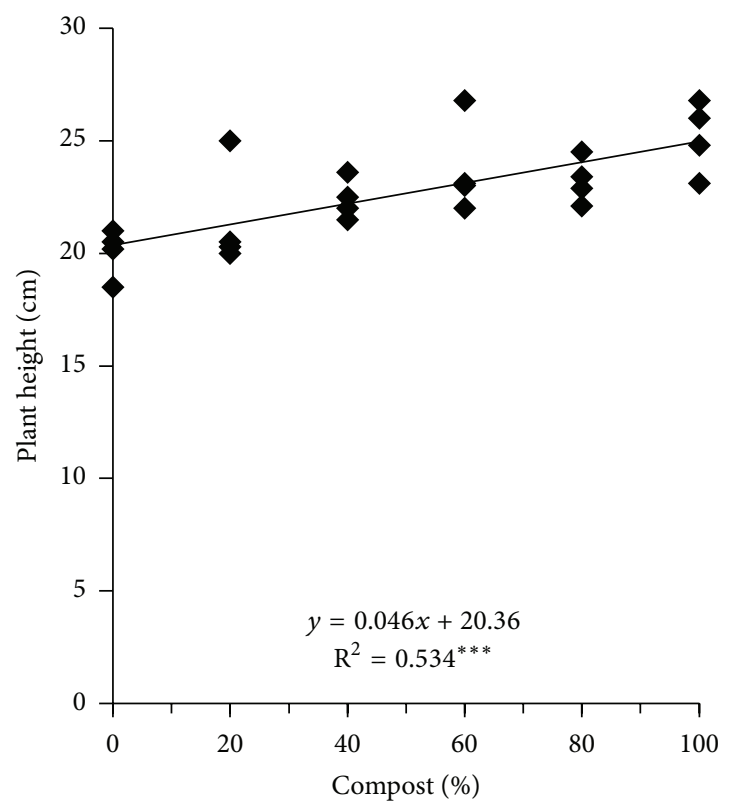

(c)

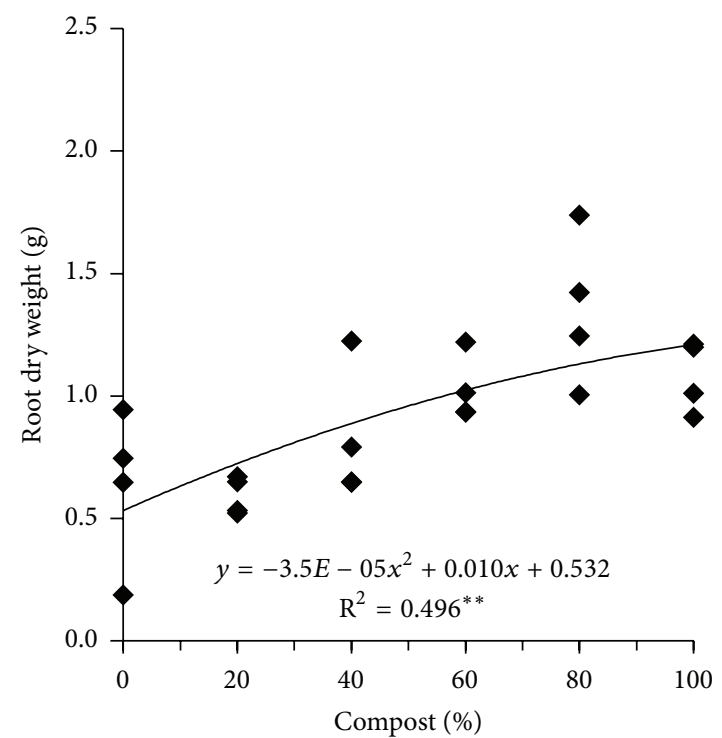

(b)

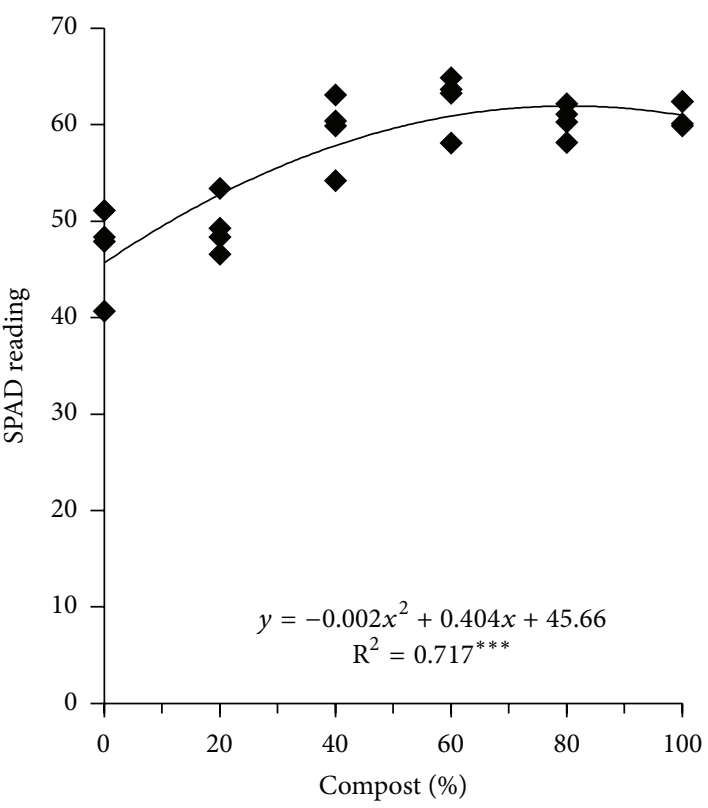

(d)

FIGURE 2: Effect of compost application rates on (a) shoot dry weight, (b) root dry weight, (c) plant height, and (d) chlorophyll meter readings (SPAD value) of oil palm seedlings. Note: ${ }^{* * * * *}$ significant at the level of 0.01 and 0.0001 probability level, respectively.

the nutrients uptake of oil palm seedlings. At low $\mathrm{pH}$, soil $\mathrm{P}$ reacted with $\mathrm{Al}$ and $\mathrm{Fe}$ oxides forming insoluble $\mathrm{Al}$ or Fe phosphate through ligand bridging and anionic repulsion rendering $\mathrm{P}$ unavailable [35]. According to Budianta et al. [36], available P concentrations increased to $73.82 \%$ when oil palm waste derived compost was applied to soil, while the soil exchangeable $\mathrm{Al}$ decreased. This could be due to the presence of the negative surface functional groups (phenolic, carboxylic, carbonyl, and alcohol) on compost immobilizing $\mathrm{Al}$ or Fe and releasing $\mathrm{P}$ back to the soil.

Furthermore, the seedling root growth was clearly associated with the bulk density, reflected by the increasing pore space and soil aeration. Addition of composted agricultural waste had been reported to significantly improve root growth $[37,38]$. The nutrients uptake increased with root growth as shown by the correlation matrix (Table 5). Thus, lower bulk density and alleviated $\mathrm{pH}$ due to compost addition were ideal to promote root growth and increased nutrients uptake and biomass.

Apart from promoting nutrient uptake, compost addition also influenced nutrient availability and retention in the growing medium. The surface of organic matter like compost is rich in negative functionalities such as phenolic, carboxylic, carbonyl, and alcohol which serve as exchange 
TABLE 4: Relationship between shoot and root dry weight, nitrogen $(\mathrm{N})$, phosphorous $(\mathrm{P})$, potassium $(\mathrm{K})$, calcium $(\mathrm{Ca})$, and magnesium $(\mathrm{Mg})$ uptake and soil $\mathrm{pH}$ as affected by compost addition in growing media.

\begin{tabular}{|c|c|c|}
\hline Interaction between soil $\mathrm{pH}$ and & Equation & $\mathrm{R}^{2}$ \\
\hline Shoot dry weight, $\mathrm{g}^{-1}$ & $y=4.233 x^{2}-37.99 x+86.42$ & $0.86^{* * *}$ \\
\hline Root dry weight, $\mathrm{g}^{-1}$ & $y=6.163 x^{2}-59.37 x+143.5$ & $0.78^{* * *}$ \\
\hline $\mathrm{N}$ uptake, mg plant ${ }^{-1}$ & $y=109.8 x^{2}-1039 x+2469.86$ & $0.84^{* * *}$ \\
\hline P uptake, mg plant ${ }^{-1}$ & $y=94.63 x^{2}-894.6 x+2123.6$ & $0.84^{* * *}$ \\
\hline $\mathrm{K}_{\text {uptake, mg plant }}{ }^{-1}$ & $y=71.15 x^{2}-677.4 x+1623.6$ & $0.85^{* * *}$ \\
\hline Ca uptake, mg plant $^{-1}$ & $y=24.58 x^{2}-236.6 x+572.3$ & $0.85^{* * *}$ \\
\hline Mg uptake, mg plant ${ }^{-1}$ & $y=20.68 x^{2}-195.2 x+463.6$ & $0.88^{* * *}$ \\
\hline
\end{tabular}

Note: ${ }^{* * *}$ significant at the level of 0.0001 probability level.

TABLE 5: Correlation matrix between dry shoot and root, nitrogen $(\mathrm{N})$, phosphorous $(\mathrm{P})$, potassium $(\mathrm{K})$, calcium $(\mathrm{Ca})$, and magnesium $(\mathrm{Mg})$ in soil and plant nutrient uptake as affected by compost addition in growing media.

\begin{tabular}{|c|c|c|c|c|c|c|c|c|c|c|c|c|c|}
\hline \multirow{2}{*}{\multicolumn{2}{|c|}{ Parameter }} & Root & Shoot & $\mathrm{N}$ & $\mathrm{P}$ & $\mathrm{K}$ & $\mathrm{Ca}$ & $\mathrm{Mg}$ & $\mathrm{N}$ & $\mathrm{P}$ & K & $\mathrm{Ca}$ & $\mathrm{Mg}$ \\
\hline & & \multicolumn{2}{|c|}{ Dry weight (g) } & \multicolumn{5}{|c|}{ Uptake (mg plant ${ }^{-1}$ ) } & \multicolumn{5}{|c|}{ Soil before treatment (\%) } \\
\hline Root & \multirow{2}{*}{ Dry weight (g) } & 1.00 & $0.57^{* *}$ & $0.81^{* * *}$ & $0.68^{* *}$ & $0.84^{* * *}$ & $0.78^{* * *}$ & $0.40^{*}$ & $0.68^{* *}$ & $0.58^{* *}$ & $-0.22^{\mathrm{ns}}$ & $0.79^{* * *}$ & $0.63^{* * *}$ \\
\hline Shoot & & & & $0.80^{* * *}$ & $0.84^{* * *}$ & $0.74^{* * *}$ & $0.86^{* * *}$ & $0.67^{* *}$ & $0.70^{* * *}$ & $0.61^{* *}$ & $-0.27^{\mathrm{ns}}$ & $0.73^{* * *}$ & $0.67^{* *}$ \\
\hline $\mathrm{N}$ & \multirow{5}{*}{ Uptake (mg plant ${ }^{-1}$ ) } & & & & $0.87^{* * *}$ & $0.92^{* * *}$ & $0.88^{* * *}$ & $0.55^{* *}$ & $0.83^{* * *}$ & $0.75^{* * *}$ & $-0.31^{\mathrm{ns}}$ & $0.86^{* * *}$ & $0.84^{* * *}$ \\
\hline $\mathrm{P}$ & & & & & & $0.82^{* * *}$ & $0.82^{* * *}$ & $0.57^{* *}$ & $0.84^{* * *}$ & $0.77^{* * *}$ & $-0.38^{\mathrm{ns}}$ & $0.83^{* * *}$ & $0.77^{* * *}$ \\
\hline K & & & & & & & $0.88^{* * *}$ & $0.55^{* *}$ & $0.82^{* * *}$ & $0.72^{* * *}$ & $-0.17^{\mathrm{ns}}$ & $0.86^{* * *}$ & $0.80^{* * *}$ \\
\hline $\mathrm{Ca}$ & & & & & & & & $0.61^{* *}$ & $0.74^{* * *}$ & $0.64^{* *}$ & $-0.27^{\mathrm{ns}}$ & $0.77^{* * *}$ & $0.71^{* * *}$ \\
\hline $\mathrm{Mg}$ & & & & & & & & & $0.50^{*}$ & $0.44^{*}$ & $-0.31^{\mathrm{ns}}$ & $0.54^{* *}$ & $0.45^{*}$ \\
\hline
\end{tabular}

Notes: $^{*, * * * * *}$ significant at the level of $0.05,0.01$, and 0.0001 probability level, respectively; ns: not significant at $p<0.05$.

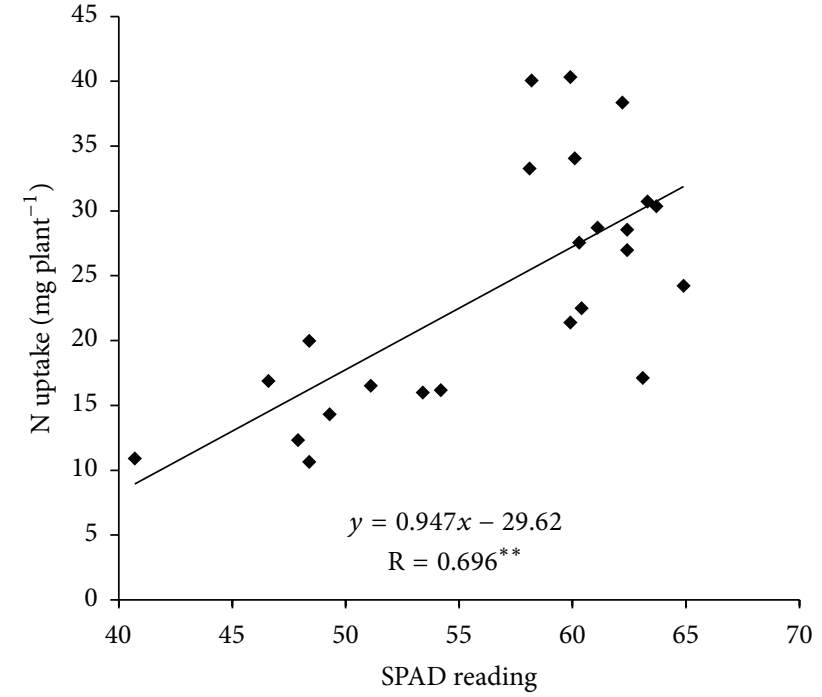

FIGURE 3: Relationship between SPAD value and plant nitrogen $(\mathrm{N})$ uptake. Note: ${ }^{* *}$ significant at the level of 0.01 probability level.

sites that ultimately increased the CEC of growth media [39]. Subsequently, it also increased dry matter production and enabled efficient nutrients usage [39-43]. This finding was consistent with Palanivell et al. [39], which reported that the application of saw dust based compost as growing media increased $\mathrm{N}, \mathrm{P}, \mathrm{K}, \mathrm{Ca}, \mathrm{Mg}$, and $\mathrm{Na}$ uptake by maize when compared to conventional fertilizer.

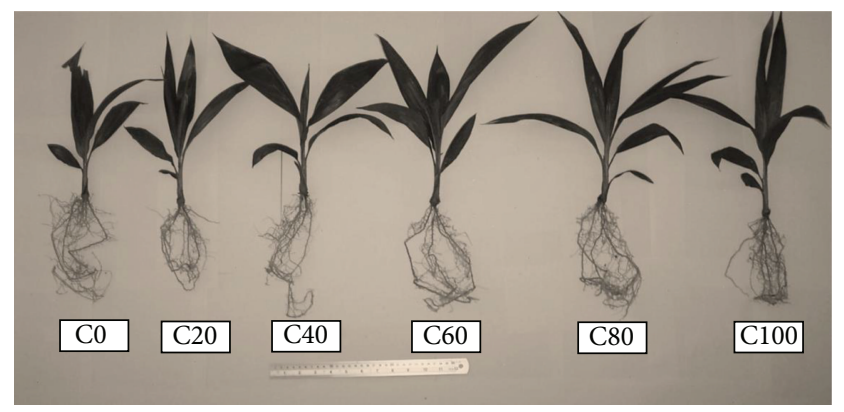

FIGURE 4: Growth of seedlings at the 12th week in prenursery stage.

However, growth of oil palm seedling is negatively affected by compost application, solely due to the high $\mathrm{C}: \mathrm{N}$ ratio, causing $\mathrm{N}$ immobilization. However, $\mathrm{C}: \mathrm{N}$ value would decrease gradually when microorganisms start breaking down the compost and slowly release plant available nutrients to the soil throughout the seedlings growth period. Similar results have been reported by [33] whereby addition of composted green waste of more than $70 \%$ caused reduction in plant growth and root morphology, probably due to the presence of phytotoxic substance and negative changes in chemical and physical properties of growth media.

\section{Conclusions}

Prenursery polybag medium amended with oil palm waste compost up to $70 \%$ increased oil palm seedling growth. 
Meanwhile, $72 \%$ of the compost mixed with topsoil could produce the best planting material with respect to the high DMW production, oil palm seedlings growth, and development as well as greater nutrient uptake. Further study is required to investigate whether the amount of chemical fertilizer employed during nursery stage could be reduced, thus cutting operational cost by making use of oil palm waste compost as polybag growth medium.

\section{Conflict of Interests}

The authors declare that there is no conflict of interests regarding the publication of this paper.

\section{Acknowledgments}

The authors would like to thank Universiti Putra Malaysia for providing the facilities and Golden Hope Plantation Bhd., Banting, for the oil palm waste that was used to produce the compost.

\section{References}

[1] Y. Basiron, "Palm oil production through sustainable plantations," European Journal of Lipid Science and Technology, vol. 109, no. 4, pp. 289-295, 2007.

[2] MPOB, "Oil palm planted area by state as at December 2014," 2014, http://bepi.mpob.gov.my/images/area/2014/Area_summary.pdf.

[3] M. A. A. Mohammed, A. Salmiaton, W. A. K. G. Wan Azlina, M. S. Mohammad Amran, A. Fakhru'L-Razi, and Y. H. Taufiq-Yap, "Hydrogen rich gas from oil palm biomass as a potential source of renewable energy in Malaysia," Renewable and Sustainable Energy Reviews, vol. 15, no. 2, pp. 1258-1270, 2011.

[4] M. M. Khan, M. A. Khan, M. Abbas, M. J. Jaskani, M. A. Ali, and H. Abbas, "Evaluation of potting media for the production of rough lemon nursery stock," Pakistan Journal of Botany, vol. 38, no. 3, pp. 623-629, 2006.

[5] M. T. Hashim, K. H. Yeow, and Y. C. Poon, "Recent development in nursery practice-potting media," in Proceedings of the International Oil Palm/Palm Oil Conferences: Progress \& Prospects. Conference 1, Agriculture, A. H. B. Hassan, Ed., pp. 369-371, Palm Oil Research Institute of Malaysia and Incorporated Society of Planters, Kuala Lumpur, Malaysia, June 1987.

[6] M. Khairil, A. A. Kamarozaman, I. Arifin, A. Ramadzan, and N. Nasir, "Evaluation of several planting media for oil palm (ElaiesGuineensis) seedlings in main nursery," in Proceedings of the Soil Science Conference of Malaysia, Kota Bharu, Malaysia, April 2012.

[7] O. O. Adeoluwa and G. O. Adeoye, "Potential of oil palm empty fruit bunch (EFB) as fertilizer in oil palm (Elaeis guineensis L. Jacq.) nurseries," in Proceedings of the 16th IFOAM Organic World Congress, Modena, Italy, June 2008, http://orgprints.org/ view/projects/conference.html.

[8] E. G. Uwumarongie-Ilori, B. B. Sulaiman-Ilobu, O. Ederion et al., "Vegetative growth performance of oil palm (Elaeis guineensis) seedlings in response to inorganic and organic fertilizers," Greener Journal of Agricultural Science, vol. 2, pp. 26-30, 2012.

[9] N. O. Aisueni and U. Omoti, "The role of compost in sustainable oil palm production," in Cutting-Edge Technologies for Sustained
Competitiveness: Proceedings of the 2001 PIPOC International Palm Oil Congress, Agriculture Conference, Kuala Lumpur, Malaysia, 20-22 August 2001, Nigerian Institute for Oil Palm, Ed., pp. 536-541, Malaysian Palm Oil Board (MPOB), 2001.

[10] F. A. Siregar, S. Salates, J. P. Caliman, and Z. Liwang, "Enhancing oil palm industry development through environmentally friendly technology," in Proceedings of the Chemistry \& Technology Conference, Indonesian Oil Palm Research Institute (IOPRI), Ed., Empty Fruit Bunch Compost: Processing and Utilities, pp. 225-234, Nusa Dua, Indonesia, July 2002.

[11] S. Ovie, M. O. Ekabafe, A. Nkechika, and O. N. Udegbunam, "Influence of composted oil palm bunch waste on soil $\mathrm{pH}$, nitrogen, organic matter status and growth of oil palm seedlings under water stress condition," Continental Journal of Agronomy, vol. 1, pp. 1-15, 2014.

[12] J. M. Bremner and C. S. Mulvaney, "Nitrogen-total," in Methods of Soil Analyses, Part 2. Chemical and Mineralogical Properties, A. L. Page, R. H. Miller, and D. R. Keeney Madison, Eds., pp. 610-615, American Society of Agronomy and Soil Science Society of America, 1982.

[13] D. E. Baker, G. W. Gorslinc, C. G. Smith, W. I. Thomas, W. E. Grube, and J. L. Ragland, "Techniques for rapid analysis of corn leaves for eleven elements," Agronomy Journal, vol. 56, pp. 133136,1964

[14] M. De Boodt and O. Verdonck, "The physical properties of the substrates in horticulture," Acta Horticulturae, vol. 26, no. 5, pp. 37-44, 1972.

[15] D. W. Nelson and L. E. Sommers, "Methods of soil analysis. Part 2. Chemical and microbiological properties," in Total Carbon, Organic Carbon, and Organic Matter, A. L. Page, R. M. Miller, and D. R. Keeney, Eds., vol. 9 of Agronomy Monograph, pp. 542560, ASA and SSSA, Madison, Wis, USA, 2nd edition, 1982.

[16] R. H. Bray and L. T. Kurtz, "Determination of total, organic, and available forms of phosphorus in soils," Soil Science, vol. 59, no. 1, pp. 39-46, 1945.

[17] M. Abad, P. Noguera, and S. Burés, "National inventory of organic wastes for use as growing media for ornamental potted plant production: case study in Spain," Bioresource Technology, vol. 77, no. 2, pp. 197-200, 2001.

[18] M. Abad, P. F. Martínez, M. D. Martínez, and J. Martínez, "Agronomic evaluation of growing media," Actas de Horticultura, vol. 11, pp. 141-154, 1993.

[19] B. Ulén, "Leaching of plant nutrients and heavy metals during the composting of household wastes and chemical characterization of the final product," Acta Agriculturae Scandinavica B: Soil \& Plant Science, vol. 47, no. 3, pp. 142-148, 1997.

[20] S. G. Sommer, "Effect of composting on nutrient loss and nitrogen availability of cattle deep litter," European Journal of Agronomy, vol. 14, no. 2, pp. 123-133, 2001.

[21] S. C. Gupta, R. H. Dowdy, and W. E. Larson, "Hydraulic and thermal properties of a sandy soil as influenced by incorporation of sewage sludge," Soil Science Society of America Journal, vol. 41, no. 3, pp. 601-605, 1977.

[22] C. J. Bronick and R. Lal, "Soil structure and management: a review," Geoderma, vol. 124, no. 1-2, pp. 3-22, 2005.

[23] A. Rivenshield and N. L. Bassuk, "Using organic amendments to decrease bulk density and increase macroporosity in compacted soils," Arboriculture \& Urban Forestry, vol. 33, no. 2, pp. 140-146, 2007.

[24] I. Celik, H. Gunal, M. Budak, and C. Akpinar, "Effects of long-term organic and mineral fertilizers on bulk density 
and penetration resistance in semi-arid Mediterranean soil conditions," Geoderma, vol. 160, no. 2, pp. 236-243, 2010.

[25] G. V. Giannakis, N. N. Kourgialas, N. V. Paranychianakis, N. P. Nikolaidis, and N. Kalogerakis, "Effects of municipal solid waste compost on soil properties and vegetables growth," Compost Science \& Utilization, vol. 22, no. 3, pp. 116-131, 2014.

[26] P. J. Valarini, G. Curaqueo, A. Seguel et al., "Effect of compost application on some properties of a volcanic soil from central South Chile," Chilean Journal of Agricultural Research, vol. 69, no. 3, pp. 416-425, 2009.

[27] T. J. Butler and J. P. Muir, "Dairy manure compost improves soil and increases tall wheatgrass yield," Agronomy Journal, vol. 98, no. 4, pp. 1090-1096, 2006.

[28] L. R. Bulluck III, M. Brosius, G. K. Evanylo, and J. B. Ristaino, "Organic and synthetic fertility amendments influence soil microbial, physical and chemical properties on organic and conventional farms," Applied Soil Ecology, vol. 19, no. 2, pp. 147$160,2002$.

[29] Y. Chen, P. Gat, F. H. Frimmel, and G. Abbt-Braun, "Metal binding by humic substances and dissolved organic matter derived from compost," in Soil and Water Pollution Monitoring, Protection and Remediation, I. Twardowska, H. E. Allen, M. M. Häggblom, and S. Stefaniak, Eds., vol. 69 of NATO Science Series, pp. 275-297, Springer, Dordrecht, The Netherlands, 2006.

[30] J. M. Xu, C. Tang, and Z. L. Chen, "The role of plant residues in $\mathrm{pH}$ change of acid soils differing in initial pH," Soil Biology and Biochemistry, vol. 38, no. 4, pp. 709-719, 2006.

[31] E. P. Jouquet, E. Bloquel, T. T. Doan et al., "Do compost and vermicompost improve macronutrient retention and plant growth in degraded tropical soils?" Compost Science and Utilization, vol. 19, no. 1, pp. 15-24, 2011.

[32] O. Gibert, D. J. Pablo, J. L. Cortina, and C. Ayora, "Sorption studies of $\mathrm{Zn}$ (II) and $\mathrm{Cu}$ (II) onto vegetal compost used on reactive mixtures for in situ treatment of acid mine drainage," Water Resources, vol. 39, pp. 2827-2838, 2005.

[33] L. Zhang, X. Sun, Y. Tian, and X. Gong, "Composted green waste as a substitute for peat in growth media: effects on growth and nutrition of Calatheainsignis," PLoS ONE, vol. 8, no. 10, Article ID e78121, 2013.

[34] G. Y. Jayasinghe, "Sugarcane bagasses sewage sludge compost as a plant growth substrate and an option for waste management," Clean Technologies and Environmental Policy, vol. 14, no. 4, pp. 625-632, 2012.

[35] W. L. Lindsay, Chemical Equilibiria in Soils, John Wiley \& Sons, New York, NY, USA, 1979.

[36] D. Budianta, P. K. S. A. Halim, N. S. Bolan, and R. J. Gilkes, "Palm oil compost reduces aluminum toxicity thereby increases phosphate fertilizer use efficiency in ultisols," in Proceedings of the 19th World Congress of Soil Science, pp. 221-223, Brisbane, Australia, August 2010.

[37] M. M. Khan, M. A. Khan, A. Mazhar, J. Muhammad, J. M. A. Ali, and H. Abbas, "Evaluation of potting media for the production of rough lemon nursery stock," Pakistan Journal of Botany, vol. 38, no. 3, pp. 623-629, 2006.

[38] S. B. Wilson, P. J. Stoffella, and D. A. Graetz, "Compostamended media for growth and development of Mexican heather," Compost Science \& Utilization, vol. 9, no. 1, pp. 60-64, 2001.

[39] P. Palanivell, K. Susilawati, O. H. Ahmed, and A. M. N. Muhamad, "Effects of crude humin and compost produced from selected waste on Zea mays growth, nutrient uptake and nutrient use efficiency," African Journal of Biotechnology, vol. 12, no. 13, pp. 1500-1507, 2013.

[40] C. Lazcano and J. Domínguez, "Soil nutrients," in The Use of Vermicompost in Sustainable Agriculture: Impact on Plant Growth and Soil Fertility, M. Miransari, Ed., p. 336, Nova Science, 2011.

[41] A. C. Petrus, O. H. Ahmed, A. M. N. Muhamad, H. M. Nasir, and $\mathrm{M}$. Jiwan, "Effect of K-N-humates on dry matter production and nutrient use efficiency of maize in Sarawak, Malaysia," TheScientificWorldJOURNAL, vol. 10, pp. 1282-1292, 2010.

[42] M. D. Perez-Murcia, R. Moral, J. Moreno-Caselles, A. PerezEspinosa, and C. Paredes, "Use of composted sewage sludge in growth media for broccoli," Bioresource Technology, vol. 97, no. 1, pp. 123-130, 2006.

[43] R. M. Atiyeh, S. Subler, C. A. Edwards, G. Bachman, J. D. Metzger, and W. Shuster, "Effects of vermicomposts and composts on plant growth in horticultural container media and soil," Pedobiologia, vol. 44, no. 5, pp. 579-590, 2000. 


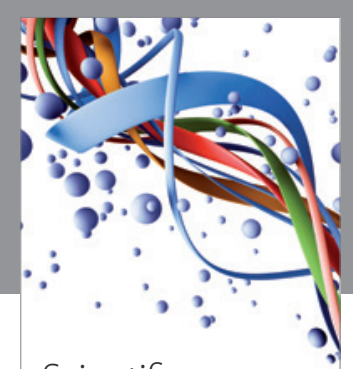

Scientifica
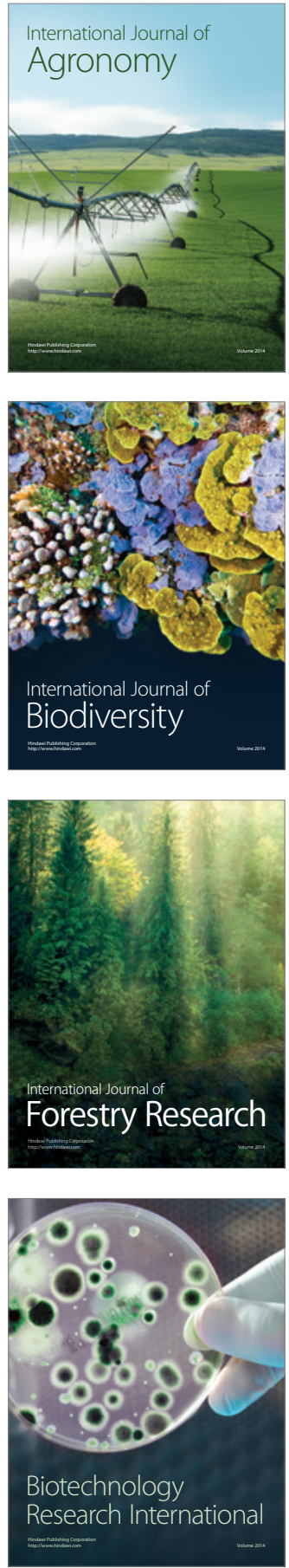
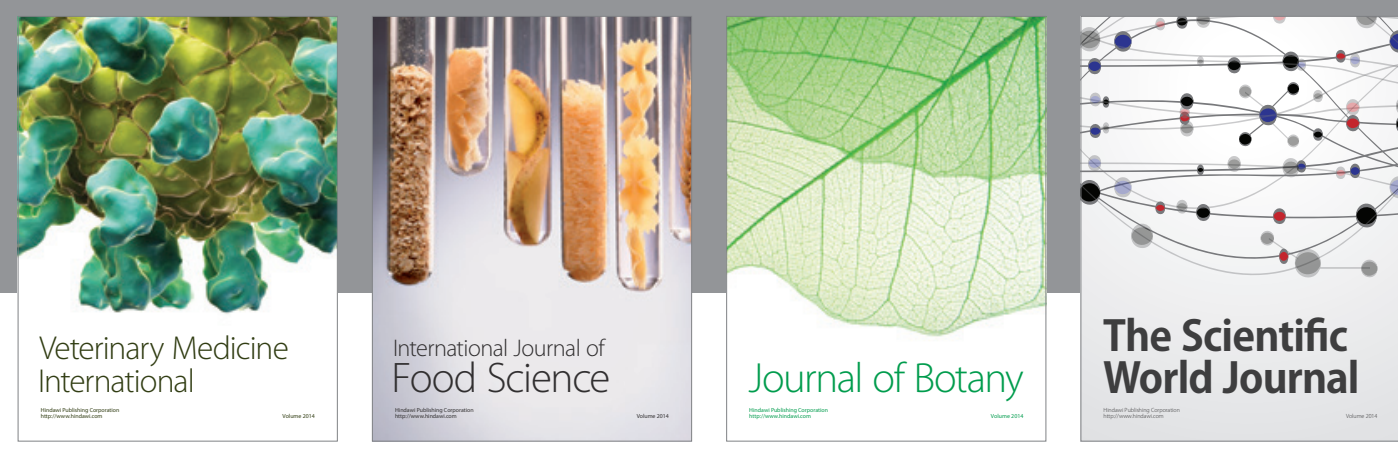

The Scientific

\section{World Journal}

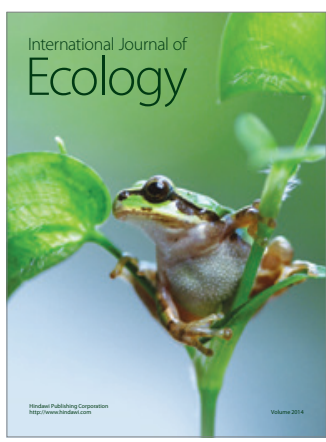

\section{Hindawi}

Submit your manuscripts at

http://www.hindawi.com
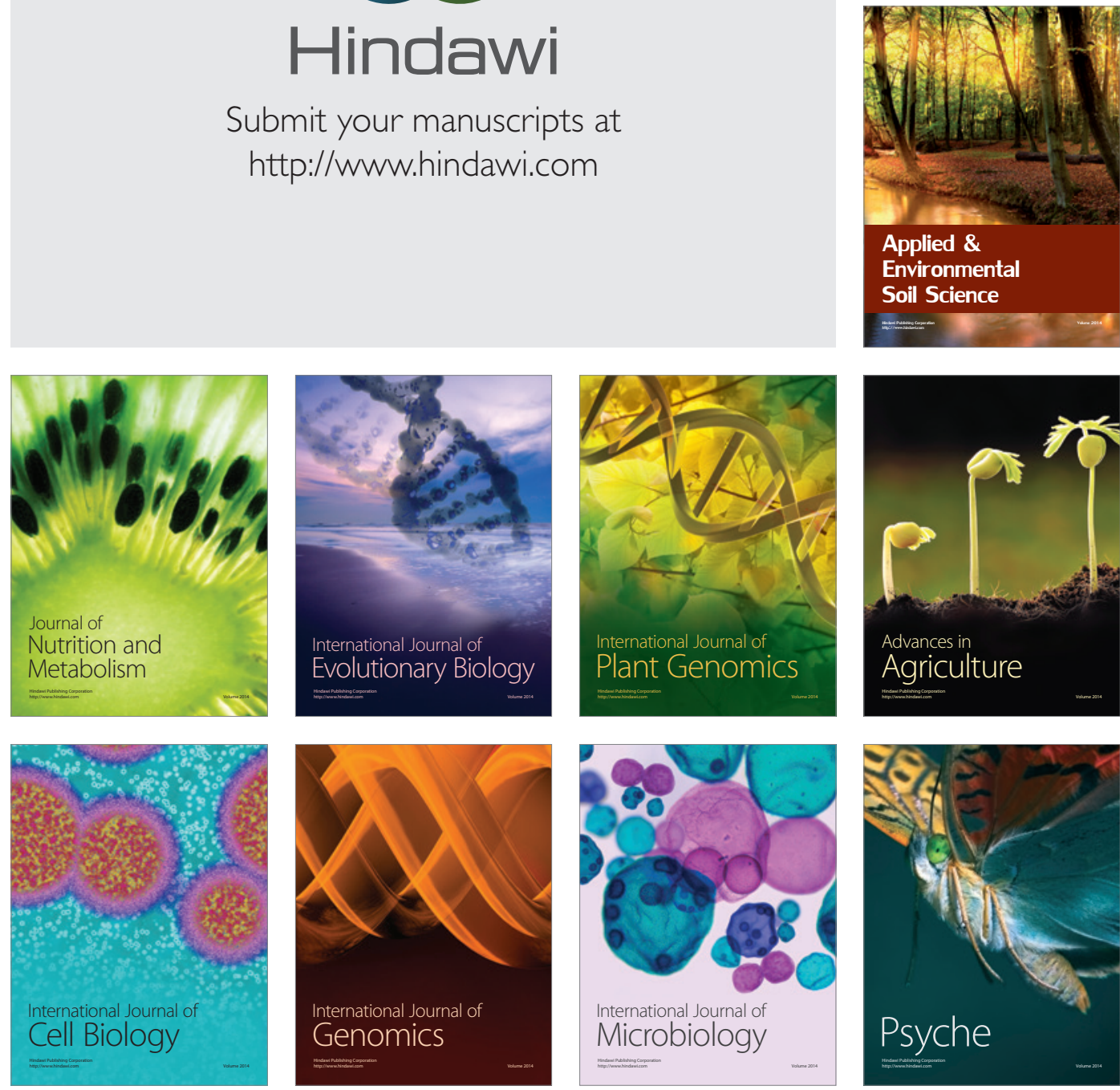
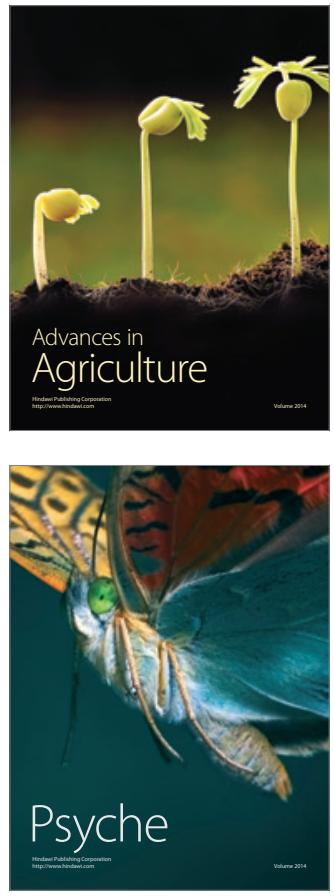